\title{
In-situ mechanical weakness of subducting sediments beneath a plate boundary décollement in the Nankai Trough
}

\author{
Yohei Hamada ${ }^{1,2}$, Takehiro Hirose ${ }^{1,2}$, Akira ljiri ${ }^{1}$, Yasuhiro Yamada ${ }^{2}$, Yoshinori Sanada $^{3}$, Saneatsu Saito ${ }^{2}$, \\ Noriaki Sakurai ${ }^{3}$, Takamitsu Sugihara ${ }^{3}$, Takahiro Yokoyama ${ }^{3}$, Tomokazu Saruhashi ${ }^{3}$, Tatsuhiko Hoshino', \\ Nana Kamiya ${ }^{4}$, Stephen Bowden ${ }^{5}$, Margaret Cramm ${ }^{6}$, Susann Henkel ${ }^{7}$, Kira Homola ${ }^{8}$, Hiroyuki Imachi', \\ Masanori Kaneko ${ }^{10}$, Lorenzo Lagostina ${ }^{11}$, Hayley Manners ${ }^{12}$, Harry-Luke McClelland ${ }^{13}$, Kyle Metcalfe ${ }^{14}$, \\ Natsumi Okutsu ${ }^{15}$, Donald Pan ${ }^{9}$, Maija Jocelyn Raudsepp ${ }^{16}$, Justine Sauvage ${ }^{8}$, Florence Schubotz ${ }^{17}$, Arthur Spivack \\ Satoshi Tonai ${ }^{18}$, Tina Treude ${ }^{19,20}$, Man-Yin Tsang ${ }^{21}$, Bernhard Viehweger ${ }^{17}$, David T. Wang ${ }^{22}$, Emily Whitaker ${ }^{23}$, \\ Yuzuru Yamamoto ${ }^{24}$, Kiho Yang ${ }^{25}$, Masataka Kinoshita ${ }^{26}$, Lena Maeda ${ }^{3}$, Yusuke Kubo ${ }^{3}$, Yuki Morono ${ }^{1}$, \\ Fumio Inagaki ${ }^{1,2}$ and Verena B. Heuer ${ }^{4}$
}

\begin{abstract}
The study investigates the in-situ strength of sediments across a plate boundary décollement using drilling parameters recorded when a 1180-m-deep borehole was established during International Ocean Discovery Program (IODP) Expedition 370, Temperature-Limit of the Deep Biosphere off Muroto (T-Limit). Information of the in-situ strength of the shallow portion in/around a plate boundary fault zone is critical for understanding the development of accretionary prisms and of the décollement itself. Studies using seismic reflection surveys and scientific ocean drillings have recently revealed the existence of high pore pressure zones around frontal accretionary prisms, which may reduce the effective strength of the sediments. A direct measurement of in-situ strength by experiments, however, has not been executed due to the difficulty in estimating in-situ stress conditions. In this study, we derived a depth profile for the in-situ strength of a frontal accretionary prism across a décollement from drilling parameters using the recently established equivalent strength (EST) method. At site C0023, the toe of the accretionary prism area off Cape Muroto, Japan, the EST gradually increases with depth but undergoes a sudden change at $\sim 800 \mathrm{mbsf}$, corresponding to the top of the subducting sediment. At this depth, directly below the décollement zone, the EST decreases from $\sim 10$ to $2 \mathrm{MPa}$, with a change in the baseline. This mechanically weak zone in the subducting sediments extends over $250 \mathrm{~m}$ ( 800-1050 mbsf), corresponding to the zone where the fluid influx was discovered, and high-fluid pressure was suggested by previous seismic imaging observations. Although the origin of the fluids or absolute values of the strength remain unclear, our investigations support previous studies suggesting that elevated pore pressure beneath the décollement weakens the subducting sediments.
\end{abstract}

Keywords: Plate boundary décollement, Nankai Trough, Excess fluid pressure, Equivalent strength, Drilling parameters, International Ocean Discovery Program (IODP), Temperature-Limit of the Deep Biosphere off Muroto (T-Limit), Site C0023, DV Chikyu

\footnotetext{
* Correspondence: yhamada@jamstec.go.jp

${ }^{1}$ Kochi Institute for Core Sample Research, Japan Agency for Marine-Earth

Science and Technology, 200 Monobe-otsu, Nankoku, Kochi 783-8502, Japan

${ }^{2}$ Research and Development Center for Ocean Drilling Science, Japan

Agency for Marine-Earth Science and Technology, 3173-25 Showa-machi,

Kanazawa-ku, Yokohama, Kanagawa 236-0001, Japan

Full list of author information is available at the end of the article
} 


\section{Introduction}

In-situ shear strength of the shallow portion of plate boundary faults and surrounding sediments is a key factor governing the development of accretionary prisms (Dahlen 1984; Davis et al. 1983), propagation of rupture during earthquakes (Kimura et al. 2012; Rice 1992; Scholz 1998), and seismicity including slow earthquakes in the shallow part of subduction zones (Ito and Obara 2006; Liu and Rice 2007; Magee and Zoback 1993; Obana and Kodaira 2009). The distributions of in-situ physical properties of frontal décollements have been determined by seismic imaging in a wide area of seismic velocity structures and reflection polarities (Bangs et al. 1996; Calahorrano et al. 2008; Moore and Shipley 1993). Several studies, based on seismic imaging, have quantitatively estimated fluid volume and pore pressure in/ around décollement zones and have found a pore pressure anomaly at the décollement zone and underlying sediments (Tobin and Saffer 2009; Tsuji et al. 2008). Because high pore pressure decreases the effective strength of formation rocks, the periphery of the frontal décollement is presumed to be mechanically weak.

The abundance of fluids has also been discussed based on chemical analysis and physical property measurement of Ocean Drilling Program/Integrated Ocean Drilling Program (ODP/IODP) core samples. On geochemical investigations of pore fluids in the core samples, broad low anomalies of chloride content in the subducting sediments were found (Gieskes et al. 1993), suggesting a surplus of water due to in-situ dehydration of clay minerals (Brown et al. 2001; Henry et al. 2003) and/or channelized lateral fluid flow from deeper portions (Kastner et al. 1993; Spivack et al. 2002). The permeability architecture of the frontal part of accretionary prisms has been constructed via laboratory measurements on core samples (Gamage and Screaton 2006) and permeability tests in boreholes (Screaton et al. 2000). Sheared clay, the main component of a shallow décollement plane, has higher permeability along the shear direction and lower permeability perpendicular to the structure. These results suggest the possibility that a décollement acts as a barrier inhibiting upward fluid convection, leading to high pore pressure and increased structural weakness of subducting sediments (Tobin et al. 2001).

Meanwhile, direct measurements of in-situ strength of a décollement or surrounding formations have not been conducted due to the difficulty in determining the in-situ stress state. It remains unknown whether the subducting sediments beneath a décollement are mechanically weak as suggested by seismic imaging data. Recently, a data processing approach was proposed by Hamada et al. (2018) to evaluate in-situ formation strength (equivalent strength, EST). The EST is an improvement of the commonly used mechanical specific energy (MSE) which is the drilling strength calculated from drilling parameters such as weight-on-bit (WOB), top drive torque $\left(T_{r}\right)$, and rotations per minute (RPM) (Bevilacqua et al. 2013; Dupriest and Koederitz 2005; Teale 1965). An evaluation of EST was undertaken at site C0002 in the IODP Nankai Trough Seismogenic Zone Drilling Project (NanTro SEIZE). A continuous strength profile to a depth of 3000 meters below the seafloor (mbsf) was obtained and used to describe the lithology (Hamada et al. 2018). This method allowed estimation of the strength without assuming uncertain in-situ conditions (e.g., stress and fluid pressure conditions). Here, we applied the EST method to drilling data obtained from IODP Expedition 370 at the Nankai Trough to evaluate the continuous in-situ strength across the toe portion of the plate boundary fault and to show the actual situation of the subducting materials beneath the décollement.

\section{Methods/Experimental}

\section{Drilling parameters of IODP Expedition 370}

IODP Expedition 370, Temperature-Limit of the Deep Biosphere off Muroto (T-Limit), was conducted in the Nankai Trough subduction zone where the Philippine Sea Plate is subducting at a rate of 4.1-6.5 cm along an azimuth of $310-315^{\circ}$ (Heki and Miyazaki 2001; Seno et al. 1993) (Fig. 1). The décollement in the Nankai Trough off Muroto is among the most studied shallow plate subduction zone on Earth, and is well distinguished by a reverse-polarity reflector on seismic reflection data (Tsuji et al. 2005; Moore et al. 1990). From the seismic velocity structure around the décollement, the underlying sediment below the décollement zone is inferred to be of low seismic velocity, which implies high porosity sustained by high fluid pressure (Tsuji et al. 2008). A new borehole at site $\mathrm{C} 0023$ was drilled at the toe portion of the accretionary prism off Cape Muroto from Sep.Nov. 2016 by D/V Chikyu (Hinrichs et al. 2016). Site C0023 was drilled on the Muroto transect approximately $3 \mathrm{~km}$ landward of the deformation front, in the vicinity of previous ODP sites 1173, 1174, and 808 (Fig. 1). The borehole depth reached 1180 mbsf penetrating the frontal portion of the décollement zone at approximately 800 mbsf and basement igneous rock at approximately 1150 mbsf (Heuer et al. 2017a). A total of 112 cores were recovered by combining three-types of coring methods: the hydraulic piston coring system (HPCS), the extended shoe coring system (ESCS), and rotary core barrel coring (RCB) (Heuer et al. 2017b).

Basic drilling parameters, such as WOB, top drive torque, RPM, and bit depth, were collected onboard the Chikyu (Fig. 2). The MSE was calculated from these parameters based on previously established conversion equations (Dupriest and Koederitz 2005; Teale 1965). Drilling data were basically recorded every second for the duration of the whole operation. For 


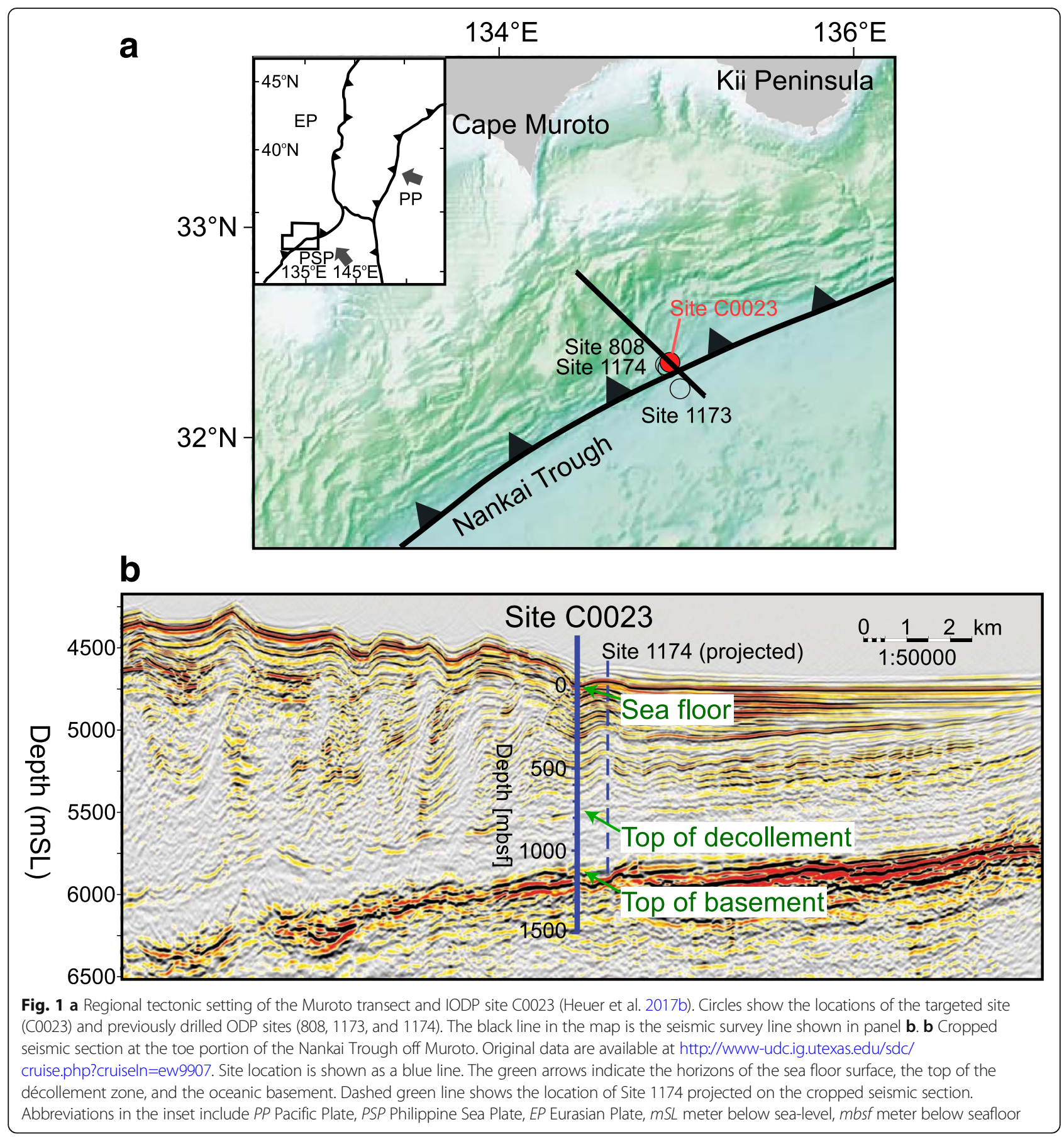

three periods, however, all drilling data is lacking because of a malfunction of the recording device (gray hatch in Fig. 2). The data can be accessed or requested at http:// sio7.jamstec.go.jp/.

\section{Evaluation of EST}

The recorded drilling parameters were converted into EST as follows (Hamada et al. 2018):

$$
\operatorname{EST}[\mathrm{Pa}]=\frac{2\left(T_{m}-T_{b}\right)}{\frac{\operatorname{ROP}}{\operatorname{RPM}}\left\{\left(\frac{R_{1}}{2}\right)^{2}-\left(\frac{R_{2}}{2}\right)^{2}\right\}},
$$

where $T_{m}$ is the measured torque and $T_{b}$ is the motley background torque. $R_{1}$ and $R_{2}$ are the external and inner diameter of the drill bit respectively. The numerator on the right hand of Eq. (1), $T_{m}-T_{b}$, corresponds to the force 


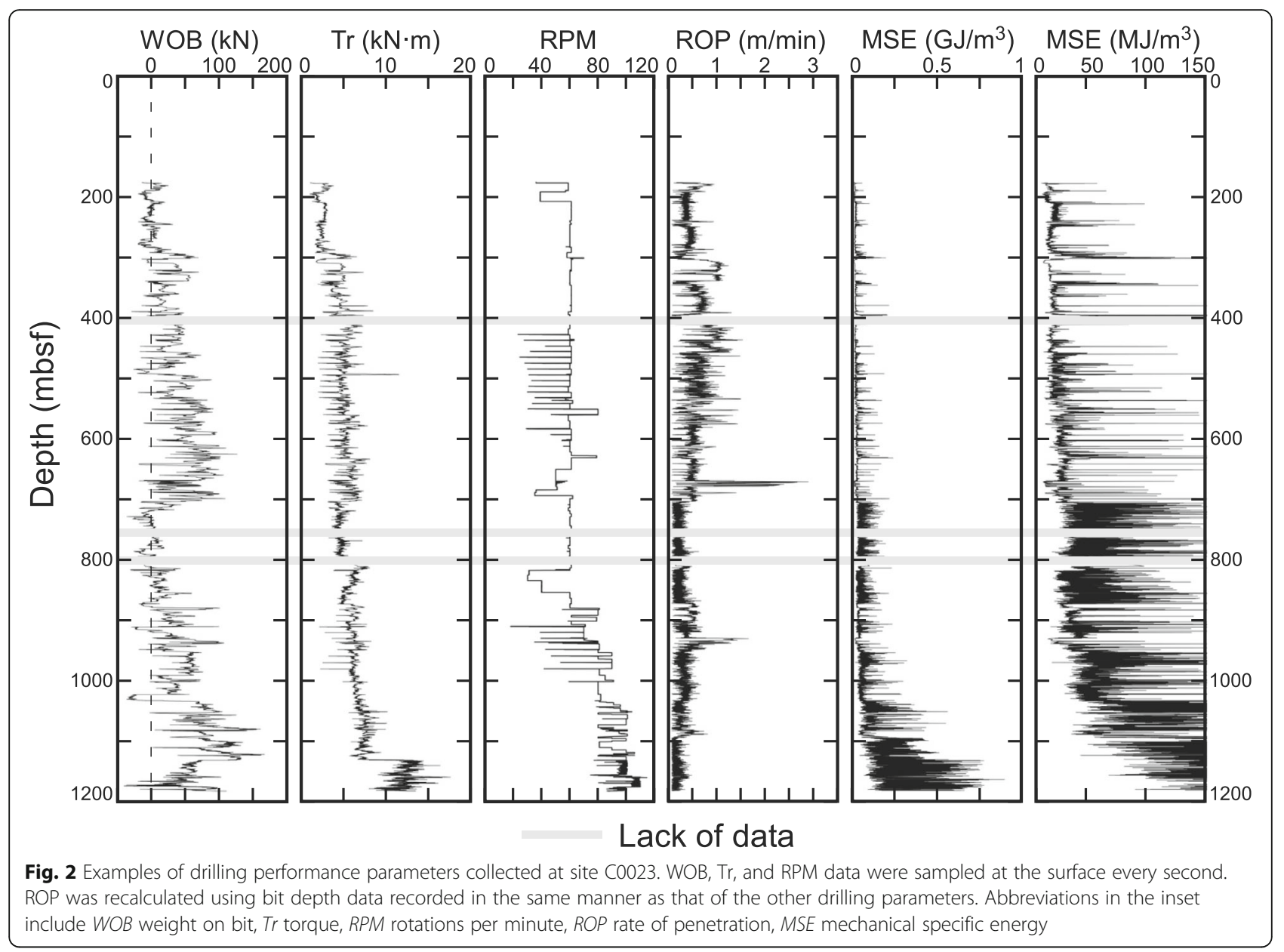

applied to the formation. $T_{b}$ is defined as a composite of torque losses except for the drilling progress and includes various resistances such as friction between the pipe and formation or the drill bit and hole bottom, lateral acceleration, whirl, and pipe (Hamada et al. 2018). Here, we assumed that $T_{b}$ can be represented by the linear function of WOB, RPM, and depth (pipe length). Using Eq. (1), the collected drilling parameters are grouped for each short time interval $(5 \mathrm{~min}$ in this study), in which RPM and depth can be considered constant. Then, the combined background torque is written as a simple function of WOB using a proportional constant $(a)$ and an intercept $(b)$ as follows:

$$
T_{b}=a \times \mathrm{WOB}+b .
$$

From Eqs. (1) and (2), the energy balance at the bit tip can be rewritten as follows:

$$
T_{m}=\mathrm{EST} \times \frac{R_{1}^{2}-R_{2}^{2}}{8 \mathrm{RPM}} \times \mathrm{ROP}+a \times \mathrm{WOB}+b .
$$

Theoretically, the relative value of the EST corresponds to the hardness of the drilled rock. Previous researches suggested that drilling energy corresponds to an approximation of in situ compressive rock strength if the background energy could be minimized (Karasawa et al. 2002; Hoberock and Bratcher 1996). However, comparison between EST and triaxial strength or other strength estimation from logging P-wave velocity (Kitajima et al. 2017) for site C0002 in the Nankai trough indicated that the values of EST may be overestimated (Hamada et al. 2018). Therefore, EST is considered only as an "equivalent strength," which can reflect the relative in-situ rock strength (triaxial shear strength) over a wide depth scale. Unfortunately, the absolute value of EST is not comparable to shear strength so far. Thus, we cannot estimate effective friction from EST calculating effective normal pressure. By linking EST and actual triaxial strength from laboratory experiments, it will be possible to discuss friction in the future.

The drilling data were first processed taking the moving average of 30-s intervals to eliminate noise and applied to Eq. (3) for each time interval of $300 \mathrm{~s}$. EST represents one gradient of the relationship between the measured torque (left-hand term) and volume progress per minute (the first term of Eq. 3). Thus, on the 
three-dimensional diagram for $T_{m}$, ROP, and WOB, EST will appear as the slope of the intersecting line between the approximate plane of the plotted drilling data for each second and the plane of WOB $=0$ (see Additional file 1: Figure S1). By this procedure, it is possible to extract information on only the bit tip, removing the background forces depending on WOB, pipe length, and tool assembly (Hamada et al. 2018). We also performed correlation analyses for each plot of 300-s time interval. The EST and $T_{b}$ were calculated when the correlation coefficient $(R)$ was $>0.6$ and $p$ value was $<0.05$ (5\%). Then EST and $T_{b}$ were obtained for each $\sim 0-5-\mathrm{m}$ depth intervals, because ROP values range from $\sim 0$ to $1 \mathrm{~m} / \mathrm{min}$ in the most of whole depth (Fig. 2). As previously mentioned in the data description section, an HPCS was employed at $305 \mathrm{mbsf}$ and 314.5-318.5 mbsf in the hole (Heuer et al. 2017a). Drilling parameters recorded during the interval were removed from the EST calculation because the drilling data does not reflect the formation strength under in-situ conditions during the HPCS coring. Because the drill bit was changed for each coring method, bit parameters in the calculation are changed according to the intervals where each coring method was employed (Table 1).

\section{Results and discussion}

\section{EST at the site $\mathrm{C} 0023$}

Figure 3 shows the conversion of drilling parameters recorded at site C0023 into EST, log EST, and background torque $\left(T_{b}\right)$ calculated based on Eq. (3) for each time interval of $300 \mathrm{~s}$, together with the employed coring assembly. The EST values were averaged within 2-m depth intervals and plotted with standard deviations to the EST values in the 2-m intervals. The EST profile was calculated continuously with depth except for at 392.5419.3, 747.5-761.3, and 792.9-809.0 mbsf where drilling data is lacking. Ranging from 1 to $10 \mathrm{MPa}$ throughout hole C0023A, EST does not show significant discontinuities at depths where coring tools or drill bits were exchanged (e.g., $400 \mathrm{mbsf}$ ), confirming that EST is not affected by coring type or bit diameter. The background torque $\left(T_{b}\right)$ increases steadily with depth. The down-hole profile of $T_{b}$ shows less fluctuations than EST and closely resembles $T_{m}$ (Fig. 2).

EST does not increase monotonically with depth but shows characteristic ups and downs (Fig. 3). To describe this variability, the EST zones were defined independently of the lithostratigraphic description. The evaluated EST indicates a gradual increasing trend in the shallower half (294-820 mbsf; zone A). In this zone, the baseline of EST shown as a blue broken line increases with depth at a gradient of $\sim 3 \mathrm{MPa} / \mathrm{km}$ and reaches $2.5 \mathrm{MPa}$ at the bottom of the zone. Zone A includes a high-EST subzone at $602-$ $648 \mathrm{~m}$ (high EST zone, HEZ). Some EST values exceed $20 \mathrm{MPa}$ in this subzone. The EST baseline is also higher than that of the adjacent intervals and reaches $\sim 7.5 \mathrm{MPa}$ approximately 630-648 mbsf. At a depth of $820 \mathrm{mbsf}$, a major discontinuity can be seen in the EST trend. In the interval between 820 and 1014 mbsf, defined as zone B, EST is slightly lower compared to the baseline of zone A (blue broken line). The EST profile in zone B appears to be constant at $5 \mathrm{MPa}$ on average. However, the difference from baseline of zone A is unclear because of EST variations of $\sim 2 \mathrm{MPa}$ in zone $\mathrm{B}$. At the top of zone B, the EST value significantly decrease from 10 to $2 \mathrm{MPa}$ in the interval between 820 to 836 mbsf. The minimum value reaches $0.9 \mathrm{MPa}$, which is equivalent to values at approximately 300-400 mbsf. We defined this low-EST zone (LEZ) (820$870 \mathrm{mbsf}$ ) as a particularly weak portion inside zone B. Below 1014 mbsf, EST again increases with depth to 1128 mbsf (zone C). EST gradually increases from approximately $5 \mathrm{MPa}$. The variation in the EST becomes more pronounced as one moves deeper. EST increases abruptly at $1128 \mathrm{mbsf}$ and reaches $80 \mathrm{MPa}$ at $1170 \mathrm{~m}$ (zone D; 1150-TD). The lowest value still exceeds $10 \mathrm{MPa}$ in this zone. For most of the borehole intervals, the relations

Table 1 Coring tool types and bit sizes with the depths of the assembly used for hole C0023A

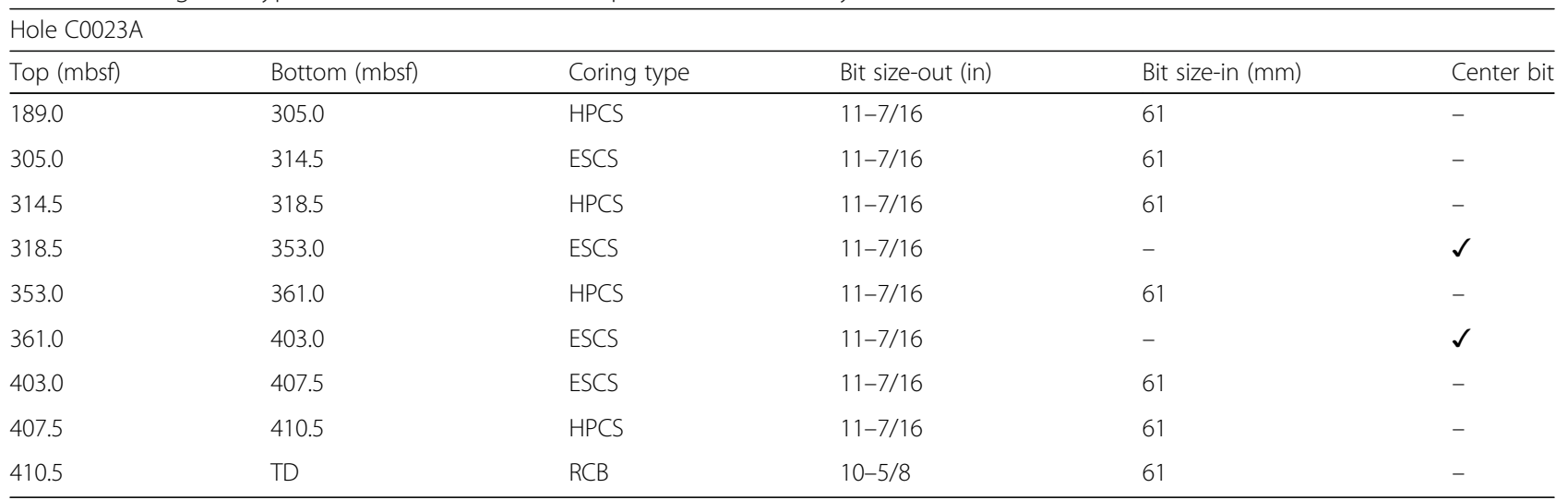

HPCS hydraulic piston coring system, ESCS extended shoe coring system, RCB rotary core barrel coring, $T D$ whole total vertical depth 


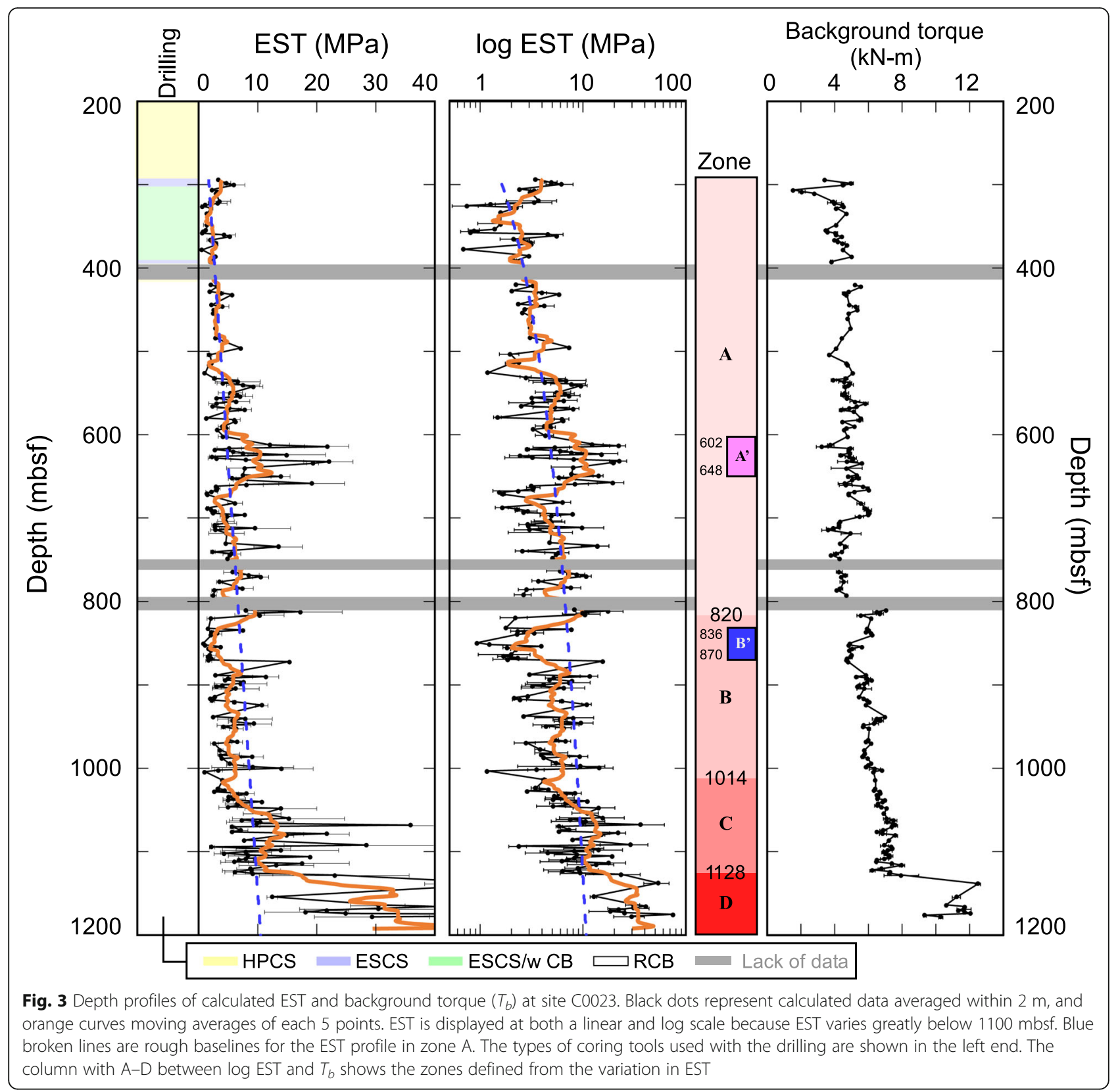

between the defined zones and the background torque are not clear. The $T_{r}$ trend indicates a monotonic increase with depth from $4 \mathrm{kN}-\mathrm{m}$ at $300 \mathrm{mbsf}$ to $7 \mathrm{kN}-\mathrm{m}$ at 1150 mbsf. Even in HEZ, where the EST rapidly changes, no significant variation is found in $T_{b}$. On the other hand, both EST and $T_{b}$ increase significantly in zone D.

\section{The low-strength zone below the décollement}

Generally, the strength of rocks increase with depth as effective pressure increases. At site C0023, however, this gradual trend is reversed at the boundary between zones A and B (820 mbsf), and in both zones considerable variations occur in the baseline (HEZ and LEZ)
(Fig. 3). Figure 4 was compiled in order to compare the EST trend with a cropped seismic image and with lithological, mineralogical, and physical observations on cores taken from site C0023. The mechanical zones defined by the EST profile do not completely correspond to the lithostratigraphic units except for unit V-basement and zone D. Unit V is characterized by varicolored clay and a high abundance of volcaniclastics. The underlying lithologic basement is composed of hyaloclastites and pillow basalts. Zone D is recognized as a sudden increase in EST, and it is plausible that the high EST values reflect the high strength of the volcaniclastics and basalts. 


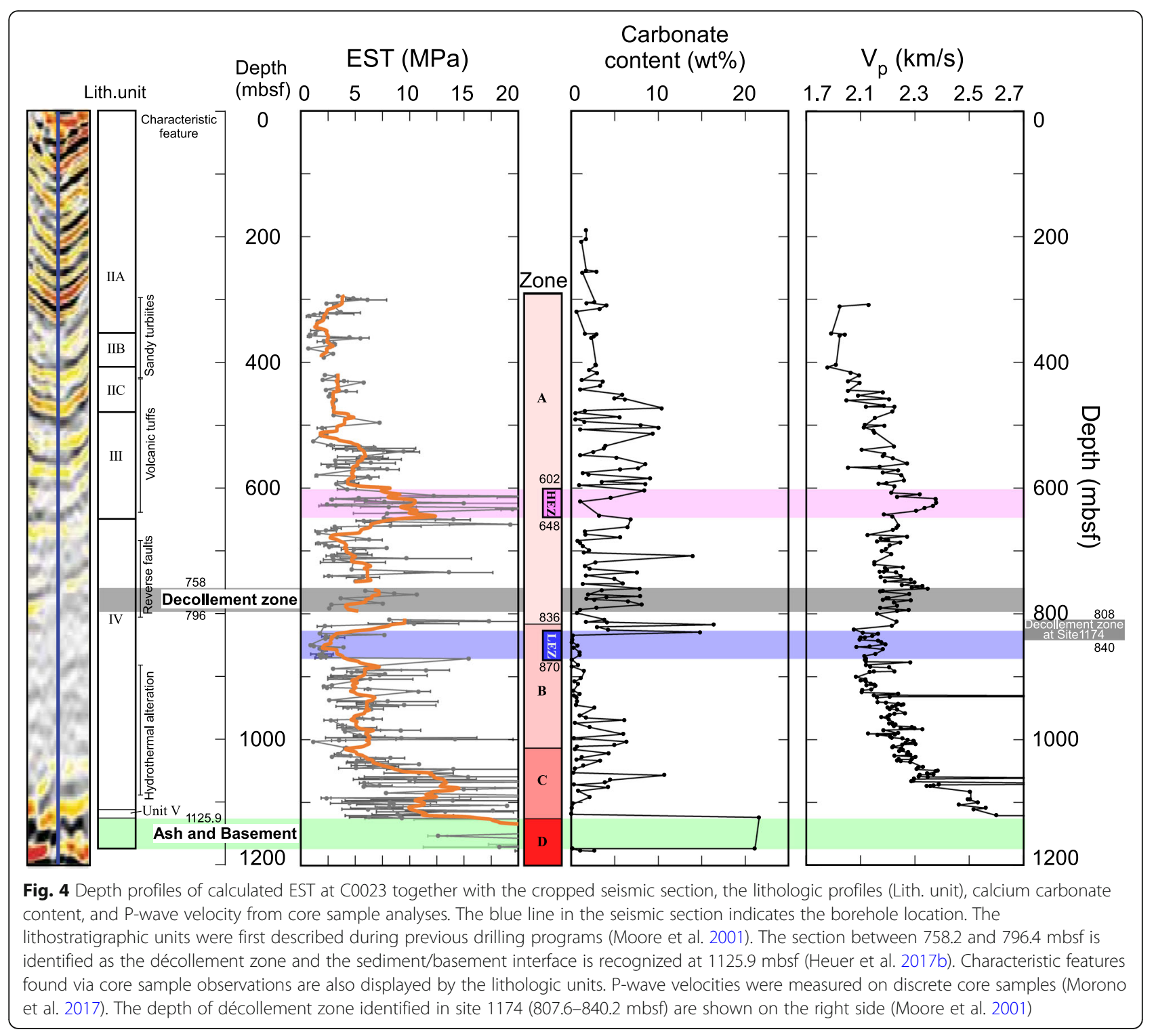

At drilling site C0002 in the Nankai Trough (IODP NanTro SEIZE), calcium carbonate content and EST show a positive relationship in the shallower portion of the boreholes (Hamada et al. 2018). Such a positive correlation is not recognized from site C0023 (Fig. 4), indicating the possibility that cementation by carbonate is not developed to the same extend in this frontal region off Muroto. On the other hand, the depth trend of P-wave velocity $\left(V_{p}\right)$, measured on core samples, corresponds closely to the EST zones (Fig. 4). In particular, both significantly increase in HEZ (600-640 mbsf), corresponding to the bottom of unit III, where repeated thick $(\sim 25 \mathrm{~cm})$ layers of volcanic ash have been recognized in core samples (Heuer et al. 2017a; Taira et al. 1991). Thus, the increase in both of $V_{p}$ and EST could reflect the physical property of stiffness in this tuffaceous layer.
Interestingly, EST neither varies clearly at the depth of the décollement zone itself nor can the décollement be characterized as an individual EST zone. EST rather significantly changes below the décollement zone (zones $\mathrm{B}$ and LEZ). A similar trend is also seen in the sample $V_{p}$. These are somewhat strange, because when there is a weak zone with lower strength than the décollement, strain can concentrate on the weak zone. One possibility to interpret the existence of this weak region is that the décollement zone identified at site C0023 is branching deformation zone, and the LEZ corresponds to the real décollement zone. The depth of the décollement zone found at previous ODP site 1174 is slightly deeper than at C0023, rather closer to LEZ (Fig. 4). On board scientists in Exp. 370, however, reported that the first major fault was found at 758.15 mbsf, interpreted to mark the 
top of the décollement zone, then no thrust fault zone was identified deeper than 796.395 mbsf (Heuer et al. 2017b). In addition, depth profiles of physical properties around the décollement zone at site C0023 show similarities with the profiles at site 1174; sample porosity increases, and P-wave velocity decreases below defined décollement zone (Taira et al. 1991; Heuer et al. 2017b). These observations and measurements suggest that the décollement zone found at $\mathrm{C0023}$ corresponds to the décollement zone identified at site 1174 . Another possibility to explain that LEZ is weaker than the décollement zone is that the actual strength of the décollement zone was not represented in EST due to low resolution of EST and/or lack of EST data. EST was calculated at 300 -s intervals. Because the ROP during penetrating the décollement zone was approximately $0.2 \mathrm{~m} / \mathrm{min}$ (Fig. 2), the calculation interval of EST is approximately every $1 \mathrm{~m}$. Furthermore, the calculated EST was rejected when the data correlation is not good $(R<0.6)$. EST cannot be calculated accurately if there is strength contrast in the data section of $300 \mathrm{~s}$ (Hamada et al. 2018). Thus, the actual strength of the décollement zone may not appear in EST if the thickness of the fault core of the décollement is thin relative to the calculation section. In fact, the décollement zone at site C0023 appears to be composed of alternating intact intervals (approximately several meters in thickness) and thinner fault zones (Heuer et al. 2017b), suggesting that the thickness of the décollement is thinner than the EST resolution. These facts indicate that the latter possibility is plausible, and LEZ is considered to be a low-strength zone existing below the décollement zone.

The décollement zone in the Nankai Trough off the Cape Muroto exists within a hemipelagic mudstone sequence of the lower Shikoku Basin in lithostratigraphic unit IV (Taira et al. 1991) (Fig. 4). No significant difference in host lithology is found above and below the décollement (Heuer et al. 2017b). Thus, the characteristic drop of EST in zone B cannot be attributed to a change in lithology. An alternative explanation is the existence of high pore fluid pressure below the décollement, which has also been noted in previous studies (Gamage and Screaton 2006; Tsuji et al. 2008). Evidence for the existence of high fluid pressure at site C0023 comes from the observation of low seismic velocity zone in seismic reflection data, which was found to be a characteristic feature in subducting sediments below the frontal décollement in this Muroto transect (Figs. 1 and 4) (Tsuji et al. 2008). The normalized pore pressure ratio $\left(\lambda^{*}\right)$ below the décollement is estimated to be $0.4-0.7$ (Tsuji et al. 2008). If the pore pressure is higher than the hydrostatic pressure (excess pore pressure), the effective pressure applied to the sediment decreases and its in-situ strength would also decrease.
The EST decreases significantly in LEZ, and this may indicate that this interval is currently under a particularly high pore pressure condition. In the $V_{p}$ profile, significant decreasing in LEZ is not observed. This is probably because the $V_{p}$ measurements have not been performed under in-situ pressure conditions. $V_{p}$ is measured on the core samples recovered on the surface whose pore pressure has been released, thus the measured $V_{p}$ values do not reflect the effect of high pore pressure at the original position. In addition, upwelling fluid from the borehole was also observed during the T-Limit project (Hirose et al. 2017). The upwelling flow was discovered by underwater TV during a re-entry operation of the drill bit, after cutting Core 110R at 1129.0 mbsf. At this time, a casing was already inserted down to $858.0 \mathrm{mbsf}$ in order to stabilize the borehole. An opening between casing and formation was not filled by concrete during the period. The fluid might possibly flow from casing interval and it reached surface through the narrow gap. It is, however, more plausible that the fluid has injected from the bare hole section between 858.0 and 1129.0 mbsf and passed through casing pipes, because the flow velocity at borehole top is high $(\sim 0.1 \mathrm{~m} / \mathrm{s})$ (Hirose et al. 2017). Thus, the upwelling flow can indicate that over-pressurized pore fluids occur at least near that depth (Hirose et al. 2017). From this observation, it is suggested that the low EST zone corresponds to a low-effective-pressure zone where fluid pressure is high because of fluid influx from clay dehydration and/or influx from a deeper portion.

As the effective pressure beneath the décollement decreases, there is a significant difference in strength between the décollement zone and the underlying sediments as demonstrated by the EST. This strength contrast possibly influences the development process of the décollement itself. Fluid permeability perpendicular to the fault plane tends to decrease with the slip displacement and the fault may act as a barrier (Faulkner et al. 2010; Tanikawa et al. 2014; Yamashita and Tsutsumi 2018). Generated or advected fluids thus flow beneath the décollement plane. As a result, the effective strength of the sediments below the décollement decreases and the strength contrast increases. This feedback effect can work once the décollement forms, promoting décollement development. Moreover, as the décollement development is repeated, the deformation may occur in the high pore pressure zone; the plate boundary fault may shift toward the lower portion. The self-development strength structure may lead to the coupling of the plate boundary to constantly weaken, resulting in a low taper angle of the accretionary prism in the Nankai Trough off the Cape Muroto. As the relationship between the absolute value of EST and the value of in situ shear strength has not been examined so far, it is impossible to evaluate 
pore fluid pressure, friction property, or other physical properties from EST. Careful examinations based on drilling experiment in laboratory and on field allow us to make a correlation between EST and strength, and to draw pore pressure structure around plate boundary décollement. In addition, comparison of the EST distribution and geochemical profiles of pore fluid or core samples will help to further elucidate the above inferences.

\section{Conclusions}

EST was evaluated from drilling parameters recorded during IODP Expedition 370 to estimate the in-situ strength across the plate boundary décollement. The depth profile of the EST from the drilling does not show a monotonic increase but indicates a significant increase from 602 to $648 \mathrm{mbsf}$ and at $\sim 1128 \mathrm{mbsf}$, as well as a strength reversal at 820 mbsf. The former depths of the high-EST zones correspond to that of a volcanic ash layer and basement, respectively, suggesting that the EST values reflect the lithologies of the drilled formations. The latter decrease in EST is directly under the décollement zone, where the existence of surplus fluids is suggested by underwater TV and seismic imaging. These results demonstrate a reduction in mechanical strength due to the high pore pressure beneath the décollement as suggested by previous research. The relation between EST and absolute values of strength will be verified in future laboratory experiments, leading to a more quantitative measurement of in-situ strength and accurate evaluation of pore fluid pressure within boreholes.

\section{Additional file}

Additional file 1: Figure S1. Strategy for converting the data and performing the t-test on the accepted datasets.Dot colors indicate the measured torque (Tm) values. (a): Diagram of the dataset for $300 \mathrm{~s}$, corresponding to 371.36-374.74 mbsf at Site C0023. Colored dots represent averaged drilling parameters for each 30-s interval. The diagram is on a plane, suggesting that the Tm depends on both WOB and RPM. (b)-(d): Projected diagram of (a) to the planes of Tm-ROP, Tm-WOB, and WOB-ROP. (PDF $357 \mathrm{~kb}$ )

\section{Abbreviations}

IODP: International Ocean Discovery Program; T-Limit: Temperature-Limit of the Deep Biosphere off Muroto

\section{Acknowledgements}

This research used data provided by the International Ocean Discovery Program (IODP). This manuscript was improved following discussions with Prof. G Kimura and Dr. Jun Kameda. We are grateful to Dr. W. Tanikawa for his repeated help with the numerical calculations. We also thank M Ikari and one anonymous reviewer for their constructive comments. The authors wish to thank Mantle Quest Japan for operating the vessel and drillings. We received generous supports from Technology Department in CDEX. We gratefully acknowledge the support provided by the operational staff of DN Chikyu and the onboard laboratory technicians (Marine Works Japan).

Funding

This study was supported by JSPS KAKENHI grant 16H04064, $15 \mathrm{H} 05717$.

\section{Availability of data and materials}

Data sharing not applicable to this article as no datasets were generated during the current study. Please contact author for data requests.

\section{Authors' contributions}

$\mathrm{YH}, \mathrm{THi}$, and $\mathrm{Al}$ proposed the topic and supervised the study. $\mathrm{LM}, \mathrm{YK}, \mathrm{VBH}, \mathrm{FI}$, and YM took the lead of IODP Expedition 370 T-Limit project as the project managers or co-chief scientists. TH, NK, SB, MC, SH, KH, HI, MKa, LL, HM, HLM, KM, NO, DP, MJR, JS, FS, AS, ST, TT, MYT, BV, DTW, EW, YUY, KY, and MKi collected shipboard and shore-based data during IODP Expedition 370. TSa, NS, TY, and TSu acquired drilling data. YH and YS conducted data processing. SS and YaY collaborated with the corresponding author in development of the manuscript. All authors reviewed and approved the final manuscript.

\section{Competing interests}

The authors declare that they have no competing interests.

\section{Publisher's Note}

Springer Nature remains neutral with regard to jurisdictional claims in published maps and institutional affiliations.

\section{Author details}

${ }^{1}$ Kochi Institute for Core Sample Research, Japan Agency for Marine-Earth Science and Technology, 200 Monobe-otsu, Nankoku, Kochi 783-8502, Japan. ${ }^{2}$ Research and Development Center for Ocean Drilling Science, Japan Agency for Marine-Earth Science and Technology, 3173-25 Showa-machi, Kanazawa-ku, Yokohama, Kanagawa 236-0001, Japan. ${ }^{3}$ The Center for Deep Earth Exploration, Japan Agency for Marine-Earth Science and Technology, 3173-25 Showa-machi, Kanazawa-ku, Yokohama, Kanagawa 236-0001, Japan. ${ }^{4}$ Department of Urban Management, Graduate School of Engineering, Kyoto University, C1-1-118 C-cluster, Kyoto Daigaku Katsura, Nishikyo-ku, Kyoto 615-8540, Japan. ${ }^{5}$ Department of Geology and Petroleum Geology, School of Geosciences, University of Aberdeen, Aberdeen AB2A 3UE, UK. ${ }^{6}$ Department of Biological Sciences, University of Calgary, 2500 University Drive Northwest, Calgary, AB T2N 1N4, Canada. ${ }^{7}$ Alfred Wegener Institute, Helmholtz Centre for Polar and Marine Research, Am Handelshafen 12, 27570 Bremerhaven, Germany. ${ }^{8}$ Graduate School of Oceanography, University of Rhode Island, 215 South Ferry Rd, Narragansett, RI 02882, USA. ${ }^{9}$ Department of Subsurface Geobiological Analysis and Research, Japan Agency for Marine-Earth Science and Technology, 2-15 Natsushima-cho, Yokosuka, Kanagawa 237-0061, Japan. ${ }^{10}$ Geomicrobiology Research Group, National Institute of Advanced Industrial Science and Technology (AIST), Chuo 7, 1-1-1 Higashi, Tsukuba 305-8569, Japan. ${ }^{11}$ Department of Environmental Systems Science, ETH Zürich, Universitätstrasse 16, 8092 Zürich, Switzerland. ${ }^{12}$ School of Geography, Earth and Environmental Sciences, Faculty of Science and Engineering, Plymouth University, Drake Circus, Plymouth, Devon PL4 8AA, UK. ${ }^{13}$ Department of Earth and Planetary Sciences, Washington University in St. Louis, One Brookings Drive, St. Louis, MO 63130-4899, USA. ${ }^{14}$ Division of Geological and Planetary Sciences, California Institute of Technology, 1200 East California Boulevard, Pasadena, CA 91125, USA. ${ }^{15}$ Atmosphere and Ocean Research Institute, The University of Tokyo, 5-1-5 Kashiwanoha, Kashiwa-shi, Chiba 277-8564, Japan. ${ }^{16}$ School of Earth Sciences, University of Queensland, St Lucia, QLD 4072, Australia. ${ }^{17}$ MARUM-Center for Marine Environmental Sciences, University of Bremen, Leobener Strasse 8, 28359 Bremen, Germany. ${ }^{18}$ Department of Natural Science, Kochi University, 2-5-1 Akebonocho, Kochi 780-8520, Japan. ${ }^{19}$ Department of Earth, Planetary, and Space Sciences, University of California, Los Angeles (UCLA), 595 Charles Young Drive East, 3806 Geology Building, Los Angeles, CA 90095-1567, USA. ${ }^{20}$ Department of Atmospheric and Oceanic Sciences, University of California, Los Angeles (UCLA), 595 Charles Young Drive East, 3806 Geology Building, Los Angeles, CA 90095-1567, USA. ${ }^{21}$ University of Toronto, 22 Russell Street, Toronto, ON M5S 3B1, Canada. ${ }^{22}$ Department of Earth, Atmospheric and Planetary Sciences, Massachusetts Institute of Technology, 45 Carleton Street, Building E25-645, Cambridge, MA 02142, USA. ${ }^{23}$ Department of Oceanography, Texas A\&M University, 797 Lamar St, College Station, TX 77843, USA. ${ }^{24}$ Department of Mathematical Science and Advanced Technology (MAT), Japan Agency for Marine-Earth Science and Technology, 3173-25 Showa-machi, Kanazawa-ku, Yokohama, Kanagawa 236-0001, Japan. ${ }^{25}$ Department of Earth System Sciences, Yonsei University, 237 Science-Hall Sinchon-dong, Seodaemun-gu, Seoul 120-749, Republic of Korea. ${ }^{26}$ Earthquake Research Institute, University of Tokyo, 1-1-1 Yayoi, Bunkyo-ku, Tokyo 113-0032, Japan. 
Received: 6 April 2018 Accepted: 9 October 2018 Published online: 03 November 2018

\section{References}

Bangs NL, Shipley TH, Moore GF (1996) Elevated fluid pressure and fault zone dilation inferred from seismic models of the northern Barbados ridge decollement. J Geophys Res Solid Earth 101:627-642

Bevilacqua M, Ciarapica FE, Marchetti B (2013) Acquisition, processing and evaluation of down hole data for monitoring efficiency of drilling processes. J Pet Sci Res 2:49-56

Brown KM, Saffer DM, Bekins BA (2001) Smectite diagenesis, pore-water freshening, and fluid flow at the toe of the Nankai wedge. Earth Planet Sci Lett 194:97-109

Calahorrano A, Sallarès V, Collot JY, Sage F, Ranero CR (2008) Nonlinear variations of the physical properties along the southern Ecuador subduction channel: results from depth-migrated seismic data. Earth Planet Sci Lett 267:453-467

Dahlen F (1984) Noncohesive critical Coulomb wedges: an exact solution. J Geophys Res Solid Earth 89:10125-10133

Davis D, Suppe J, Dahlen F (1983) Mechanics of fold-and-thrust belts and accretionary wedges. J Geophys Res Solid Earth 88:1153-1172

Dupriest FE, Koederitz WL (2005) Maximizing drill rates with real-time surveillance of mechanical specific energy. In SPE/IADC Drilling Conference. Society of Petroleum Engineers, In Amsterdam

Faulkner D, Jackson C, Lunn R, Schlische R, Shipton Z, Wibberley C, Withjack M (2010) A review of recent developments concerning the structure, mechanics and fluid flow properties of fault zones. J Struct Geol 32:1557-1575

Gamage K, Screaton E (2006) Characterization of excess pore pressures at the toe of the Nankai accretionary complex, ocean drilling program sites 1173, 1174, and 808: results of one-dimensional modeling. J Geophys Res Solid Earth 111:B04103. https://doi.org/10.1029/2004JB003572

Gieskes JM, Gamo T, Kastner M (1993) 31. Major and minor element geochemistry of interstitial of site 808, Nankai Trough: an overview. In: Hill IA Taira A, Firth JV et al (eds) Proceedings of the ocean drilling program. Scientific Results, vol 131, pp 387-396

Hamada Y et al (2018) Continuous depth profile of the rock strength in the Nankai accretionary prism based on drilling performance parameters. Sci Rep 8:2622

Heki K, Miyazaki S (2001) Plate convergence and long-term crustal deformation in central Japan. Geophys Res Lett 28:2313-2316

Henry P, Jouniaux L, Screaton EJ, Hunze S, Saffer DM (2003) Anisotropy of electrical conductivity record of initial strain at the toe of the Nankai accretionary wedge. J Geophys Res Solid Earth 108:2407. https://doi.org/10. 1029/2002JB002287

Heuer VB, Inagaki F, Morono Y, Kubo Y, Maeda L, the Expedition 370 Scientists (2017a) Expedition 370 Preliminary Report: Temperature Limit of the Deep Biosphere off Muroto International Ocean Discovery Program. https://doi.org/ 10.14379/iodp.pr.370.2017

Heuer VB, Inagaki F, Morono Y, Kubo Y, Maeda L, the Expedition 370 Scientists (2017b) Temperature limit of the deep biosphere off Muroto. In: Proceedings of the International Ocean Discovery Program, vol 370. International Ocean Discovery Program, College Station. https://doi.org/10.14379/iodp.proc.370.2017

Hinrichs K, Inagaki F, Heuer V, Kinoshita M, Morono Y, Kubo Y (2016) Expedition 370 scientific prospectus: T-Limit of the deep biosphere off Muroto (T-Limit). International Ocean Discovery Program. https://doi.org/10.14379/iodp.sp.370. 2016

Hirose T, Kamiya N, Yamamoto Y, Heuer VB, Inagaki F, Kubo Y, Scientists the Expedition 370 Scientists (2017) Fluid pressure development beneath the décollement at the Nankai subduction zone: its implications for slow earthquakes. In: American Geophysical Union Fall Meeting Abstracts

Hoberock LL, Bratcher GJ (1996) A new approach for determining in-situ rock strength while drilling. ASME J Energy Resour Technol 118:249-255

Ito Y, Obara K (2006) Very low frequency earthquakes within accretionary prisms are very low stress-drop earthquakes. Geophys Res Lett 33:L09302

Karasawa H, Ohno T, Kosugi M, Rowley CJ (2002) Methods to estimate the rock strength and tooth wear while drilling with roller-bits-part 1: milled-tooth bits. J Energy Resour Technol 124:125. https://doi.org/10.1115/1.1482405

Kastner M et al (1993) 32. Geochemnical and isotopic evidence for fluid flow in the western Nankai subduction zone Japan. Proceedings of the Ocean Drilling Program. Sci Results 131:397-413

Kimura G, Hina S, Hamada Y, Kameda J, Tsuji T, Kinoshita M, Yamaguchi A (2012) Runaway slip to the trench due to rupture of highly pressurized megathrust beneath the middle trench slope: the tsunami genesis of the 2011 Tohoku earthquake off the east coast of northern Japan. Earth Planet Sci Lett 339:32-45

Kitajima H, Saffer D, Sone H, Tobin H, Hirose T (2017) In situ stress and pore pressure in the deep interior of the Nankai accretionary prism, integrated Ocean Drilling Program Site. Geophys Res Lett 44:9644-9652. https:/doi.org/ 10.1002/2017GL075127

Liu Y, Rice JR (2007) Spontaneous and triggered aseismic deformation transients in a subduction fault model. J Geophys Res Solid Earth 112:B09404. https:// doi.org/10.1029/2007JB004930

Magee ME, Zoback MD (1993) Evidence for a weak interplate thrust fault along the northern Japan subduction zone and implications for the mechanics of thrust faulting and fluid expulsion. Geology 21:809-812

Moore G, Shipley T (1993) Character of the décollement in the Leg 131 area, Nankai Trough. In: Proceedings of the Ocean Drilling Program. Scientific Results, pp 73-82

Moore GF et al (1990) Structure of the Nankai Trough accretionary zone from multichannel seismic reflection data. J Geophys Res Solid Earth 95:8753-8765

Moore GF et al (2001) New insights into deformation and fluid flow processes in the Nankai Trough accretionary prism: results of Ocean Drilling Program Leg 190. Geochem Geophys Geosyst 2:1058. https://doi.org/10.1029/2001GC000166

Morono Y et al (2017) Expedition 370 methods. In: Heuer VB, Inagaki F, Morono Y et al (eds) Proceedings of the International Ocean Discovery Program, vol 370

Obana K, Kodaira S (2009) Low-frequency tremors associated with reverse faults in a shallow accretionary prism. Earth Planet Sci Lett 287:168-174

Rice JR (1992) Fault stress states, pore pressure distributions, and the weakness of the San Andreas fault. In: Fault Mechanics and Transport Properties of Rocks, edited by B. Evans and T.-F. Wong, Academic Press, San Diego, pp. 475-503

Scholz CH (1998) Earthquakes and friction laws. Nature 391:37

Screaton E, Carson B, Davis E, Becker K (2000) Permeability of a decollement zone: results from a two-well experiment in the Barbados accretionary complex. J Geophys Res Solid Earth 105:21403-21410

Seno T, Stein S, Gripp AE (1993) A model for the motion of the Philippine Sea plate consistent with NUVEL-1 and geological data. J Geophys Res Solid Earth 98:17941-17948

Spivack AJ, Kastner M, Ransom B (2002) Elemental and isotopic chloride geochemistry and fluid flow in the Nankai Trough. Geophys Res Lett 29(14): 1661. https://doi.org/10.1029/2001GL014122

Taira A, Hill I, Firth J (1991) Proceedings of the Ocean Drilling Program: initial reports: (Ocean Drilling Program)

Tanikawa W, Tadai O, Mukoyoshi H (2014) Permeability changes in simulated granite faults during and after frictional sliding. Geofluids 14:481-494

Teale R (1965) The concept of specific energy in rock drilling. In: International Journal of Rock Mechanics and Mining Sciences \& Geomechanics Abstracts 1:57-73

Tobin H, Vannucchi P, Meschede M (2001) Structure, inferred mechanical properties, and implications for fluid transport in the décollement zone, Costa Rica convergent margin. Geology 29:907-910

Tobin HJ, Saffer DM (2009) Elevated fluid pressure and extreme mechanical weakness of a plate boundary thrust, Nankai trough subduction zone. Geology 37:679-682

Tsuji T, Tokuyama H, Costa Pisani P, Moore G (2008) Effective stress and pore pressure in the Nankai accretionary prism off the Muroto peninsula, southwestern Japan. J Geophys Res Solid Earth 113:B11401. https://doi.org/ 10.1029/2007JB005002

Tsuji T et al (2005) Initiation of plate boundary slip in the Nankai Trough off the Muroto peninsula, southwest Japan. Geophys Res Lett 32:L12306

Yamashita T. Tsutsumi A (2018) Fluid-flow properties of fault zones. In: Involvement of Fluids in Earthquake Ruptures. Springer, Tokyo, pp 51-71 